\title{
大麦糠プロアントシアニジンのヒアルロニダーゼ, リポキシゲナーゼ阻害活性及び抗補体活性
}

\author{
玉川浩司 ${ }^{*} \cdot$ 飯塚崇史 ${ }^{*} \cdot$ 池田彰男* ·小池 肇* $\cdot$ 長沼慶太* $・$ 小宮山美弘** \\ Inhibitory Effects of Proanthocyanidins Isolated from Barley \\ Bran on Hyaluronidase Activity, Soybean Lipoxygenase \\ Activity and Complementary Activity
}

\author{
Koji Tamagawa*, Satoshi IrzuKA* Akio IKedA*, Hazime KoikE*, \\ Keita NAGANUMA* and Yoshihiro KomIYAMA** \\ * Research and Development Center, Hakubaku Co., Ltd., \\ 3492 Aoyagi, Masuho-cho, Yamanashi, 400-0501 \\ ** The Yamanashi Industrial Technology Center, 2517, Katsunuma, \\ Katsunuma-cho, Yamanashi, 409-1316
}

\begin{abstract}
The effects of proanthocyanidin (dimer and trimer) isolated from BPE (a polyphenol extract from barley bran) on hyaluronidase activity, soybean lipoxygenase activity and complementary activity in vitro were studied in comparison with catechins. Inhibition to these activities was depended on BPE concentration. Inhibition of proanthocyanidins to hyaluronidase was more effective than that of $(+)$-catechin, $(-)$-epicatechin and (-)-epigallocatechin, however, less effective than that of $(-)$ epigallocatechin gallate ((-)-EGCG) and (-)-epicatechin gallate ((-)-ECG). The inhibitory effects of proanthocyanidins on lipoxygenase activity were found to be higher than those of catechins. The anti-complementary activities of proanthocyanidins except procyanidin B 3 were found to be same or more effective than those of (-)-EGCG and (-)-ECG. These results suggested that BPE and proanthocyanidins isolated from BPE might be good inhibitors to inflammation and allergic reaction.

(Received, Feb. 16, 1999 ; Accepted, Apr. 14, 1999)
\end{abstract}

著者らはこれまで，食用大麦を製造する際，大量に発 生する大麦棣中のポリフェノール成分に着目し，そこか ら抽出した大麦ポリフュノール抽出物BPE (Polyphenol extract from barley bran) 及びその主ポ リフェノール成分であるプロアントシアニジン類の機能 特性について検討してきた，その結果, BPE が優れた抗 酸化能及び活性酸素消去能を有していること口や BPE より分離精製したブロデルフィニジン類がカテキン類と 比較して, 同等あるいはそれ以上の活性酸素消去能2), 生体モデル系における脂質酸化抑制作用 ${ }^{3)}$ を有している ことを明らかにした．また，ガン予防に関係する機能と
して，抗変異原性 ${ }^{2)}$ やゲニステイン4) やダイゼイン゙) と 同様に，白血病細胞の分化を促進して脱ガンに至らせる 作用を有していだ).

近年, ポリフェノール成分の新たな機能特性として抗 アレルギー作用が着目されている。 緑茶 ${ }^{(2)-9) ， シ ソ(0) 11) ~}$ 及び甜茶 ${ }^{22}$ 等に含まれるポリフェノール成分が，種々の アレルギー反応を抑制することが報告されている。 ま た，最近では，これらの成分を既製の食品に添加した抗 アレルギー効果を補足した食品 (ブラス食品) の開発が 行われている(3). 実際にポリフェノール類を有効成分と した茶カテキン、 シソエキス, 甜茶エキス等を添加して

* (株)はくばく研究開発センター（干400-0501 山梨県南巨摩郡增穂町最勝寺 3492）

** 山梨県工業技術センター（テ409-1316 山梨県東山梨郡勝沼町勝沼 2517） 
抗アレルギー作用を期待した食品が製品化されてい $\Xi^{14)}$.

そこで著者らは，大麦糠より分離したポリフェノール 抽出物 BPE に抗アレルギー作用があるか否かを検索す るための基礎的な特性を，幾つかのアレルギー活性測定 法を用いて検討した. また，BPEの主ポリフェノール成 分であるプロアントシアニジン類の作用についてす同様 にカテキン類と比較検討した。

\section{実 験 方 法}

1. 大麦糠からのポリフェノール抽出物 BPE の抽出 及びプロアントシアニジンの分離

既報1) と同方法にて, n-ヘキサンにより脱脂した六条 大麦（カナダ産，B1602，1995 年度収穫）の搗精棣（步留 まり 80 90\% 区分） $1 \mathrm{~kg}$ より，Folin-Denis 法 ${ }^{15)}$ での 湘定により (十)-カテキン換算で $28.7 \%$ のポりフェノー ル類を含む大麦ポリフェノール抽出物（BPE） $10 \mathrm{~g}$ を作 製した. BPEからのプロアントシアニジンの分離は MCMURROUGH らの方法 ${ }^{16)}$ に準じ調製した。 すなわち， メタノールで平衡化した Sephadex LH-20 (ファルマシ ア社製）カラム $(920 \times 30 \mathrm{~mm}$ I.D. $)$ に，大麦ポリフェ ノール抽出物 $1.0 \mathrm{~g}$ を吸着させ, メタノールにて流量 1.5 $\mathrm{ml} / \mathrm{min}$ の条件で溶離し, 溶出液の $280 \mathrm{~nm}$ の吸光度を 測定した. 各プロアントシアニシンの精製はODS-3 （GLサイエンス社製， $250 \times 20$ mm I.D.）分取用カラム を用い, 脱イオン水とメタノール（共に $0.2 \%$ キ酸含有） の直線的な濃度勾配により溶出, 分離した. 精製後の各 プロアントシアニジンの純化程度は, ODS-80 Ts (TOSO 社製， $250 \times 4.0 \mathrm{~mm}$ I.D.) 分析用カラムで調べ た．また，LC-MS（M-1200AP，日立製作所社製）によ り分子量を確認した. 分離精製したプロアントシアニジ ンの化学構造を Fig. 1 に示した. 大麦プロアントシアニ ジンと抗アレルギー活性を比較したカテキン類は, 市販 の特級試薬 (シグマ社製) を使用した.

\section{2. ヒアルロニダーゼ阻害活性試験}

測定法については, KAKEGAWA らの方法 ${ }^{17)} に$ 準じた. すなわち, 脱イオン水に溶解した試料（BPEについては 反応系濃度で 10 300 mg\%，プロアントシアニジン及 びカテキン類については $0.1 〜 2.0 \mathrm{mM}$ となるように調 製) $100 \mu l$ に酵素溶液（ヒアルロニダーゼーType IV-S From Bovine Testes，シグマ社製 $-8 \mathrm{mg}$ を酢酸緩㣫䘸 （pH 4.0） $2 \mathrm{ml}$ に溶解） $50 \mu l$ を加えた． $37^{\circ} \mathrm{C}$ で 20 分間 放置後, 酵素活性化溶液 (Compound $48 / 80$, シグマ社 製 $-2 \mathrm{mg}$ 及び $\mathrm{CaCl}_{2} \cdot 2 \mathrm{H}_{2} \mathrm{O} \quad 15 \mathrm{mg}$ を酢酸緩衝液 $4 \mathrm{ml}$

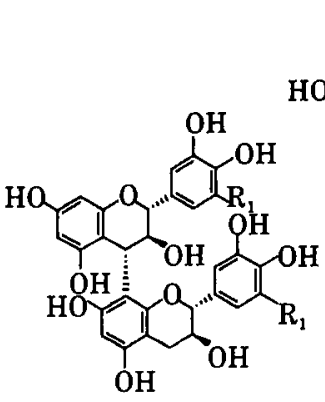

Dimer

Procyanidin $\mathrm{B} 3, \mathrm{R}_{1}=\mathrm{H}$ Prodelphinidin $\mathrm{B} 3, \mathrm{R}_{1}=\mathrm{OH}$

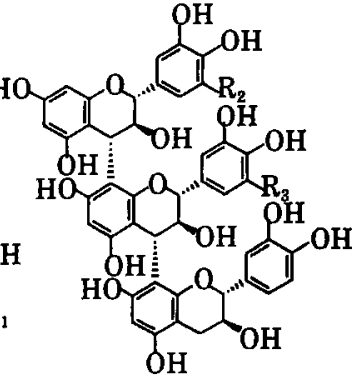

Trimer
Prodelphinidin T2 $\mathrm{R}=$

Prodelphinidin T3, $\mathrm{R}_{2}=\mathrm{H}, \mathrm{R}_{3}=\mathrm{OH}$ Procyanidin $T 4, R_{2}=R_{3}=H$

Fig. 1 Structures of proanthocyanidins isolated from BPE

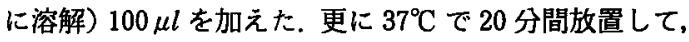
基質溶液（ヒアルロン酸（鶏冠製，和光純薬工業社製） $8 \mathrm{mg}$ を酢酸縓衝液 $10 \mathrm{ml}$ に溶解) $250 \mu l$ を加えて, $37^{\circ} \mathrm{C}$ で 40 分間反応させた. その後， $0.4 \mathrm{~N}$ 水酸化ナトリウム $100 \mu l$ を加え反応を停止させた後，ホウ酸カリウム溶液 $(0.8 \mathrm{M}$ ホウ酸水溶液 $100 \mathrm{~m} l$ に水酸化カリウム $2.24 \mathrm{~g}$ を 加え溶解） $100 \mu l$ を加え，沸騰水浴中にて 3 分間加熱し た. 室温まで水道水で冷却後, p-ジメチルベンズアルデ ヒド試液（p-ジメチルベンズアルデヒド $5 \mathrm{~g}$ を水酰酸 $44 \mathrm{~m} l, 10 \mathrm{~N}$ 塩酸 $6 \mathrm{ml}$ に溶解, 用時水酢酸にて 10 倍希 釈) $3.0 \mathrm{ml}$ を加え, $37^{\circ} \mathrm{C}$ で 20 分間放置後の $585 \mathrm{~nm}$ の吸 光度（ヒアルロン酸がヒアルロニダーゼによって分解さ れたNーアセチルグルコサミンの生成量）を測定した. 尚，試料の代わりに脱イオン水を用いたものを対照と し, 各試料，対照について酵素溶液を入れないブランク を設定し，次式により阻害活性（\%) を算出した.

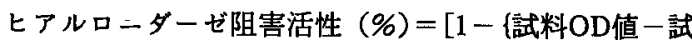
料ブランクOD值 $\}$ / \{対照OD值一対照ブランクOD值 $\}] \times$ 100

3. 大豆由来リポキシゲナーゼの阻害活性の測定法 測定法は KOMODA らの方法 ${ }^{18)}$ に準じた．各試料を溶 解したメタノール溶液（BPEについては，反応系濃度で $2 \sim 10 \mathrm{mg} \%$ ，プロアントシアニジン及びカテキン類に ついては, 20〜100 $\mu \mathrm{M}$ となるように調製)をホウ酸緩衙 液（pH 9.0） $2.0 \mathrm{ml}$ に加えてよく湿合した，次にホウ酸 緩衝液に溶解した大豆由来りポキシゲナーゼ（シグマ社 製, type I-B) 溶液 $20 \mu l$ (1000 unit に相当) を加え，5 分間窑温で放置した．その後，エタノールに溶解した 
$4.18 \mathrm{mM}$ リノール酸溶液 $50 \mu l$ を加え, $25^{\circ} \mathrm{C}$ にて 234 $\mathrm{nm}$ の吸光度により，20 分間の間リポキシゲナーゼの残 存活性による共役ジェンの生成を確認した. 尚, 阻害活 性は試料溶液の代わりに 50\%メ夕ノール溶液を添加し たものを対照とし，以下の式により算出した.

阻害活性 $(\%)=[1-$ (試料を添加した系の1 20分間の OD值の増加)]/[対照の1〜20分間のOD值の增加 $] \times 100$

\section{4. 抗補体活性の測定法}

測定法は DAY らの方法 ${ }^{19)}$ に準じた。すすなわ， $15 \mathrm{ml}$ 容のスクリューキャップ付き遠沈管を用いて, pH 7.5 に 調製した $0.15 \mathrm{mM} \mathrm{CaCl}_{2}, 0.50 \mathrm{mM} \mathrm{MgCl}_{2}$ 及び $0.1 \%$ ラチンを含むべロナール緩衝液 $\left(\mathrm{GVB}^{2+}\right) 2 \mathrm{ml}$ 之陚料 (BPEについては反応系漂度で 5〜 $100 \mathrm{mg} \%$, プロアン トシアニジン及びカテキン類については 10〜 500 $\mu \mathrm{M}$ と なるように調製） $200 \mu l$ を湿合擋拌した．更に脱イオン 水に溶かしたヒト血清（㭪体コントロール $0.5 \mathrm{ml}$ 用, デ ンカ生研製）溶液 $10 \mu l$ を入れて擋找した．次に $\mathrm{GVB}^{2+}$ に希釈した感作ヒッジ赤血球（デンカ生研製）溶液を $200 \mu l$ 添加・擋挥した後, $37^{\circ} \mathrm{C}$ の水浴中で 60 分間反応 させた. その後, 水水中にて 10 分間放置し, 反応を停止 させた. 反応液を $2000 \mathrm{rpm}$ で 10 分間遠心分離し，未溶 血の赤血球を分離した後，その上澄み液の $540 \mathrm{~nm}$ にお ける吸光度を測定した，尚，試料の代わりに脱イオン水 を用いたものを対照とし，各試料，対照について血清を 入れないブランクを設定し, 次式により抗補体活性を求 めた.

抗補体活性 $(\%)=[1-$ 侙料OD值一試料ブランク OD 値 $\} /$ 対照OD値一対照ブランクOD值 $\} \times 100$

\section{結果及び考察}

\section{BPEのヒアルロニダーゼ活性に対する阻害}

$\mathrm{BPE}$ がヒアルロニダーゼ活性に及ばす影響を検討し た. 結果を Fig. 2 に示す. BPE は濃度依存的にヒアルロ ニダーゼ活性を阻害し， $300 \mathrm{mg} \%$ は，55\% の阻害率 を示した. ヒアルロニダーゼはヒアルロン酸の加水分解 酵素でありI型アレルギー（即時型）に関与するケミカ ルメディエーターの1つであるヒスタミンと同時に肥满 細胞や好塩基球から脱顆粒により遊離する. 本醭素は炎 症に深く関与する酵素であるとされ，数種の抗アレル ギー薬においてヒアルロニダーゼの阻害と肥満細胞から のヒスタミン遊離抑制に正の相関が認められている ${ }^{20)}$. BPEがヒアルロニダーゼ活性を阻害したことは, BPE が I 型アレルギーに関与する炎症を㧕制する可能性があ ることを示唆している.

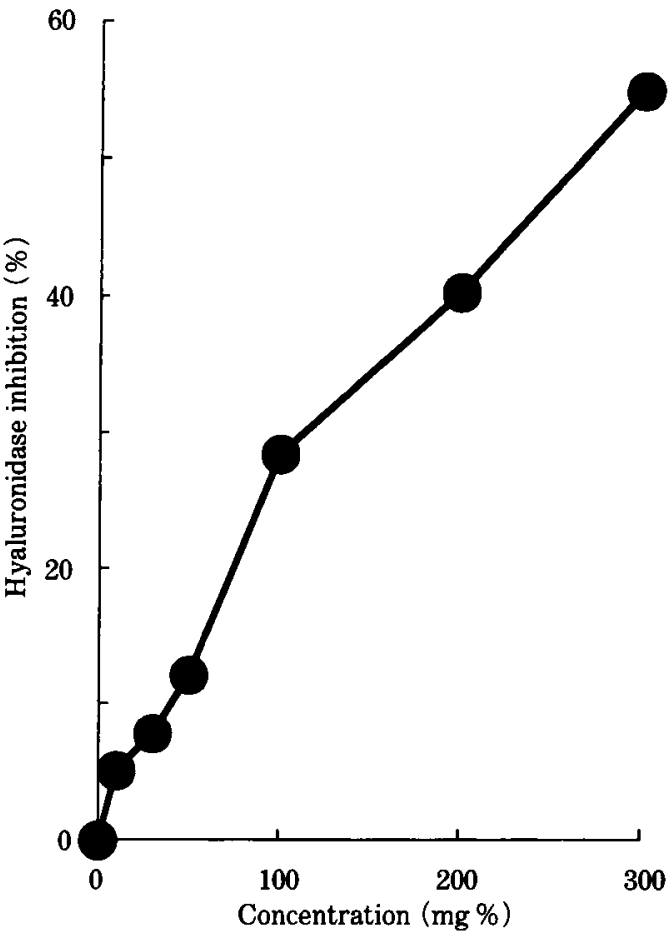

Fig. 2 Inhibitory effect of BPE concentration on hyaluronidase activity

The percentage inhibition (mean of two expriments) was calculated as follows : Inhibition (\%)

$$
=\frac{\left\{\begin{array}{l}
1-(\text { Sample OD } 585 \mathrm{~nm} \\
- \text { Sample blank OD } 585 \mathrm{~nm})
\end{array}\right\}}{\left(\begin{array}{c}
\text { Control OD } 585 \mathrm{~nm} \\
- \text { Control blank OD } 585 \mathrm{~nm}
\end{array}\right)} \times 100
$$

2. BPE より分離したプロアントシアニジン及びカ テキンのヒアルロニダーゼ活性に対する阻害

BPE より分離したプロアントシアニジン及びカテキ ンのヒアルロニダーゼ活性に及ぼす影幚を検討した． 結 果をFig. 3 に示す. プロアントシアニジン類において は, プロデルフィニジンT 2 及びプロシアニジン T 4 の $\mathrm{IC}_{50}$ 值 (50\% 阻害濃度) がそれぞれ $0.4 \mathrm{mM}$ 及び 0.55 $\mathrm{mM}$ を示し，(一)-ECG 及び（一)-EGCG に匹敵する七 アルロニターゼ阻害活性を示した. しかし，ヒアルロ二 ダーゼ活性をより高い比率で阻害する濃度は，(一) ECG及び(一)-EGCG と比較して小さかった. 他のプロ アントシアニジン類の酵素阻害活性は, (+)-C, (-)EC 及び（一)-EGC と比較して大きかった。

FACINO らは，牛精巣由来のヒアルロニダーゼ活性に 


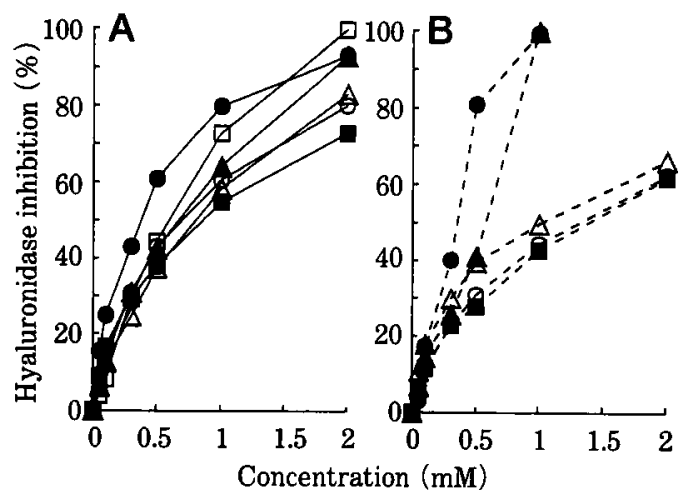

Fig. 3 Inhibitory effect of proanthocyanidins isolated from BPE and catechins on hyaluronidase activity

The values are means of two experiments. A : Proanthocyanidins B : Catechins Prodelphinidin B 3; $\bigcirc$, Procyanidin B 3; $\triangle$, Prodelphinidin $\mathrm{T} 1 ;-0$. Prodelphinidin $\mathrm{T} 2 ; \longrightarrow$, Prodelphinidin $\mathrm{T} 3$; $-\square$, Procyanidin $\mathrm{T} 4 ; \cdots \odot \cdots,(-)$-Epicatechin ; ...- ..... (+)-Catechin ; $\cdots \Delta \cdots . \quad(-)-$ Epigallocatechin ; -...., (-)-Epicatechin gallate ; $\cdots . \cdots,(-)$-Epigallocatechin gallate

対するブドウ種子由来のプロシアニジン（平均分子量 1800）の阻害効果について唡討しており，カテキンは効 果がなかたが, プロシアニジンの $\mathrm{IC}_{50}$ 值は $80 \mu \mathrm{M}$ で あったと報告している21).また，プロシアニジン B 1 (PB 1), B 2 (PB 2) 及びC1（PC 1) とエピカテキンの 抗ヒアルロニダーゼ活性は, PC 1>PB 2>PB 1>エピカ テキンの順に大きかったと報告されている22)。これらの 実験結果の傾向は，本報での結果とよく一致しており, プロアントシアニジン類が BPEのヒアルロニダーゼ活 性の阻害に深く関与していることが推察された.

\section{BPEの大豆由来リボキシゲナーゼ活性の阻害}

BPE が大豆由来リポキシゲナーゼに及ぼす影響を検 討した. 結果を Fig. 4 に示す. BPE は濃度依存的にリポ キシゲナーゼを抑制し， $10 \mathrm{mg} \%$ で，52\%の阻害活性 を示した生体内においてリポキシゲナーゼ代謝産物は, アレルギーや炎症と密接な関係があると考えられてお $り^{23)}, \mathrm{BPE}$ が生体内においても同様の効果を示すことが 期待される.

4. BPEより分離したプロアントシアニジン及びカ テキン類の大豆由来リポキシゲナーゼ活性の阻害 プロアントシアニジヌびカテキンのリポキシゲナー

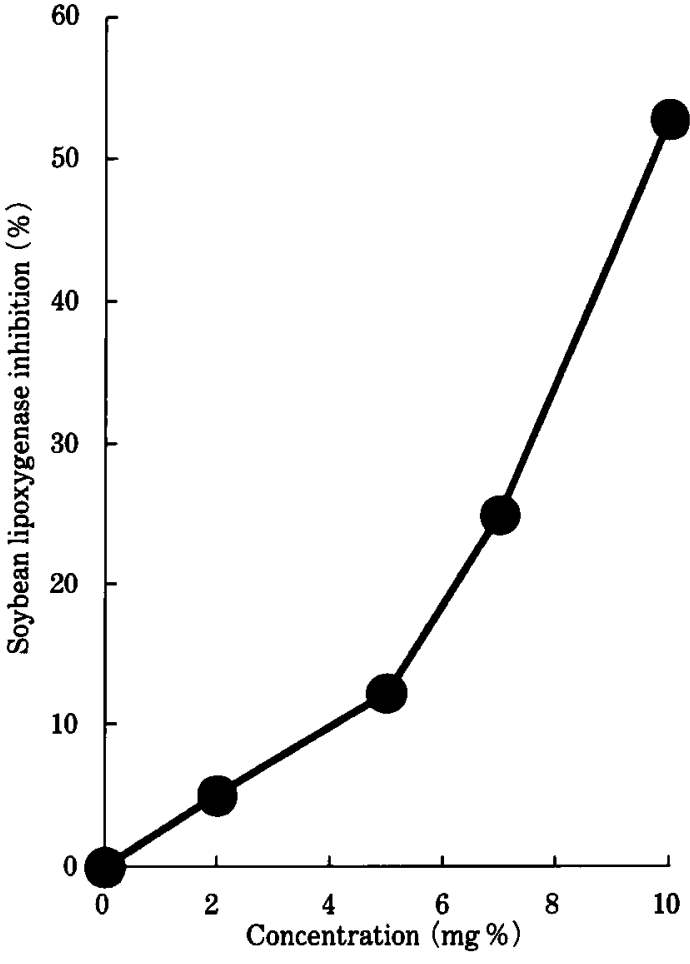

Fig. 4 Inhibitory effect of BPE concentration on soybean lipoxygenase activity

The values are means of two experiments.

ゼに及ぼす影帮を検討した．結果を Fig. 5 に示す．プロ アントシアニジン類においては，リポキシゲナーぜの $\mathrm{IC}_{50}$ 值でプロデルィニジン T 1 及び T 2 が阻害活性が 最も大きく，その值は約 $32 \mu \mathrm{M}$ でおった. 次いでプロデ ルフィニシン T $3(41 \mu \mathrm{M})$, プロシアニジンT 4 (44 $\mu \mathrm{M})$ の順であった. これらの成分は $100 \mu \mathrm{M}$ で $90 \%$ 以 上の阻害活性を示した. プロアントシアニジンの 2 量 体, 即ちプロデルフィニジン B 3 及びプロシアニジン B 3 はブロアントシアニジン 3 量体と比較してその阻害活 性は小さかった. しかし，カテキン類の中で䣼素阻害活 性が大きかった (-)-EGCG 及び(一)-ECG と比較する と, その阻害活性は大きかった，(-)-EGC，(-)-EC 及 び（十）-C は $100 \mu \mathrm{M}$ の反応系濃度においてす，酵素阻 害活性は 30〜 40\% でありプロアントシアニシン類と比 較してその効果は非常に小さかった.

Ho らは, カテキンの大豆由来 15-リポキシゲナーゼ 活性測定時の阻害活性における $\mathrm{IC}_{50}$ 值は, (-)-EGCG, (一)-ECG 及び(一)-EGC が 10〜 $21 \mu \mathrm{M}$ であったのに 


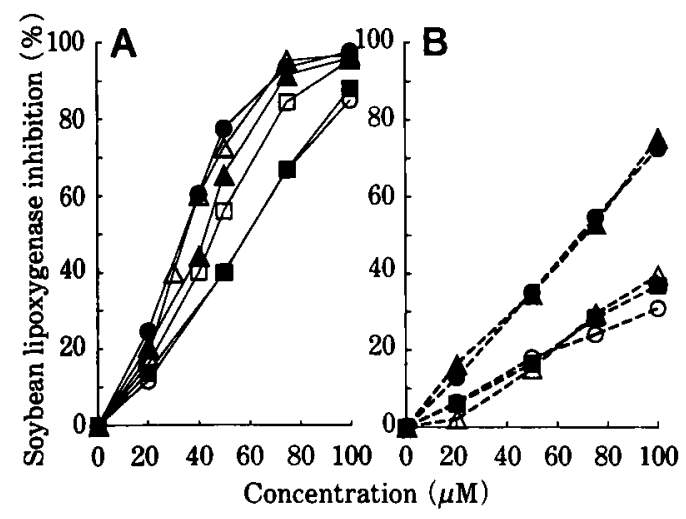

Fig. 5 Inhibitory effects of proanthocyanidins isolated from BPE and catechins on soybean lipoxygenase activity

The values are means of two experiments.

A : Proanthocyanidins B: Catechins

Symbols are the same as those in Fig. 3.

対し，(-)-EC は $140 \mu \mathrm{M}$ と阻害活性が非常に小さかっ たと報告している24).この傾向は，本試験の結果と比較 し, (一)-EGC の阻害活性度が大きい点が異なるが, 酵 索の調製法あるいは精製度の違いによるものと推定され た.これらのことから, 大麦棣より分離した BPEのリポ キシゲナーゼ抑制能にプロアントシアニジン，特にプロ デルフィニジンが強く関与しているあのと思われた.

\section{BPE の抗補体活性}

BPEが補体の活性化に及ぼす影響を検討した，結果 をFig. 6 に示す. BPE は祳度依存的に補体の活性化を 抑制し, $100 \mathrm{mg} \%$ 濃度では， $82 \%$ の補体価を抑制した. 補体系は炎症や II 型（細胞障害型，細胞融解型）及び而 型（免废複合型，アルサス型）アレルギー反応の病体生 理に重要な役割を果たしている ${ }^{25)}$ ．また，補体価の抑制 は抗アレルギー活性の指標の一つと考えられており ${ }^{26)}$, BPE が II 型及び血型アレルギー反応を抑制する可能性 が示唆された.

6. BPE より分離したプロアントシアニジン及び

\section{テキン類の抗補体活性}

プロアントシアニジン及びカテキンが補体活性に及ば す影響を検討した．結果を Fig. 7 に示す. プロアントシ アニジンにおいては, プロデルフィージン T 1 の $\mathrm{IC}_{50}$ 值 （㭪体価を $50 \%$ 阻害する濃度）が $52 \mu \mathrm{M}$ と最す大きく， $200 \mu \mathrm{M}$ で $90 \%$ 以上の㭪体価の抑制を示した。次いでそ の作用が大きかったのは, プロデルフィニジン T 2 であ

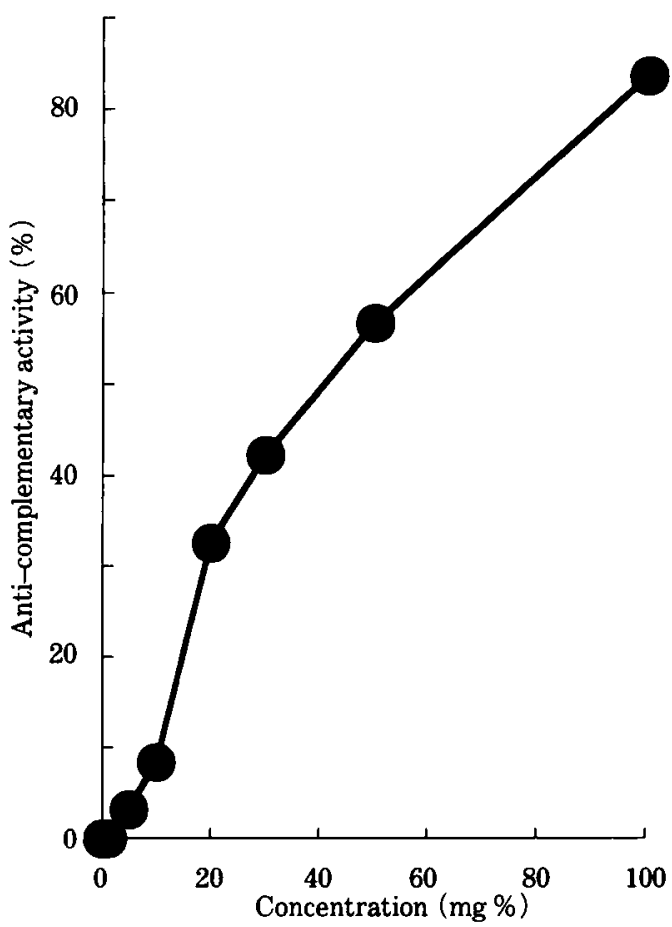

Fig. 6 Effect of BPE concentration on anticomplementary activity

The values are means of two experiments.

Activity (\%) was calculated by the equation used in Fig. 2.

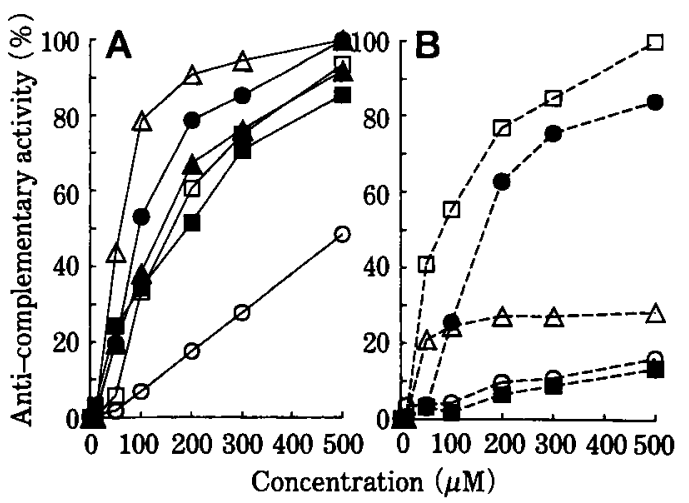

Fig. 7 Effects of proanthocyanidins isolated from BPE and catechins on anticomplementary activity

The values are means of two experiments. A : Proanthocyanidins B: Catechins Symbols are the same as those in Fig. 3. 
り，その $\mathrm{IC}_{50}$ 值は（一)-EGCGに匹敵した。 プロデル フィニジン T 3， B 3 及びプロシアニジンT 4 は (-)ECG とほぼ同等の補体価の抑制を示した. プロシア二 ジンB 3 は, 他のプロアントシアニジンと比較してその 効果はかなり小さかったが，(-)-EC 及び（+)-C と比 較すると大きかった。

SHAHAT らはバラ科の葉や果物よりルチンやケルセチ ンなどのフラボノィド類, エピカテキン及びプロアント シアニジン類を分離精製し，それらの感作ヒッジ赤血球 に対する抗補体価について検討しており，プロアントシ アニジン類がエピカテキンと比較し, 補体価の抑制がか なり大きいことを報告している27)、本結果はこれらの結 果を確認するものであり，大麦のプロアントシアニジ ン, 特にプロデルフィニジンが, BPE の感作ヒッジ赤血 球に対する補体作用の抑制に貢献していることが判明し た.

本研究では大麦ポリフェノール抽出物 (BPE) 及びそ の主ポリフェノール成分であるプロアントシアニジンの in vitroでの抗アレルギー作用を検討したあのであり， 抗アレルギー作用に関する直接の証明については，動物 実験等により確認する必要があると考えられる。

要 約

大麦糠由来のポリフょノール抽出物 BPE 及びそこか ら分離精製したプロアントシアニジン類（2 量体及び 3 量体）について，幾つかの抗アレルギー活性測定法を用 いそその効果を検討した。

(1) BPE は，生体内における炎症に深く関与してい るヒアルロニダーゼ活性を濃度依存的に抑制した。 ま た，その主要ポリフェノール成分であるプロアントシア ニシン類の抗ヒアルロニダーゼ活性は，(-)-EGCG 及 (一)-ECGと比較して，小さかったが，(-)-EGC, (-)-EC 及び（+)-Cよりは大きかった.

(2) 大豆リポキシゲナーゼ活性についてあ濃度依存的 に抑制し，また，その主要ポリフェノール成分であるプ ロアントシアニジン類の抗リポキシゲナーゼ活性は，力 テキン類と比較して大きいことが判明した。

(3) 感作ヒッジ赤血球における補体価の抑制は BPE の濃度に依存して大きくなった。また，その主要ポリ フェノール成分であるプロアントシアニジン類の抗補体 活性は，(-)-EGCG 及 (-)-ECG 之同等あるいはそれ 以上の効果を示した。

\section{文献}

1）玉川浩司・飯塚崇史・福島 誠・遠藤好司・小宮 山美弘: 食科工, 44, 512 (1997).

2）玉川浩司・飯塚容史・小堀真珠子・新本洋士・津 志田藤二郎 : 食科工, 45, 420 (1998).

3）玉川浩司・飯塚崇史・池田彰男・小池 竍・長沼 慶太・小宮山美弘 : 食科工, 46, 106 (1999).

4) Constantinou, A., Kiguchi, K. and Huberman, E. : Cancer Res., 50, 2618 (1990).

5) Jing, Y., Nakay A, K. and Han, R. : Anticancer Res., 13, 1049 (1993).

6) Tamagawa, K., Fukushima, S., KoborI, M., SHINMOTO, H. and Tsushida, T.:Biosci. Biotechnol. Biochem., 62, 1483 (1998).

7) Matsuo, N., Yamada, K., Shoji, K., Mori, M. and Sugano, M. : Allergy, 52, 58 (1997).

8) Shirai, T., Sato, A., Chida, K., Hayakawa, H., Akiyama, J., IWata, M., TANiguchi, M., Reshad, K. and HARA, Y.: Ann. Allergy Asthma Immunol., 79, 65 (1997).

9) Matsuo, N., Yamada, K., Yamashita, K., ShoJi, K., Mori, M. and Sugano, M. : In vitro Cell Dev. Biol. Anim., 32, 340 (1996).

10）山本浩代 : 食品之開発，32，41（1997）.

11) ImAOKA, K., INOUYE, S., TAKAHASHI, T. and Колма, Ү.: Arerugi (in Japanese), 42, 74 (1993).

12）中原光一: フードケミカル，9，44（1995).

13）仁科淳良 : Food Style 21，2，69 (1998).

14）仁科淳良 : Food Style 21, 2, 69 (1998).

15) A.O.A.C. : Official and Tentative Methods of Analysis of A.O.A.C., 8th Ed., P. 144 (1955).

16) McMurrough, I., Loughrey, M. J. and Hennigan, G.P.: J. Sci. Food. Agric., 34, 62 (1983).

17) Kakegawa, H., Matsumoto, $H$. and Sato, T.: Chem. pharm. Bull., 33, 642 (1985).

18) Komoda, T., Morimitsu, $Y$., Hirota, H. and Hirota, A. : Biosci. Biotechnol. Biochem., 59, 924 (1995).

19) DAY, N.K., Winfield, J.B., GEE, T., WinchesteR, R., Teshima, H. and Kunkel, H.G. : Clin. Exp. Immunol., 26, 189 (1976).

20) Kakegawa, H., Matsumoto, H. and Sato, T.: Chem. pharm. Bull., 33, 642 (1985).

21) Facino, M. R., Carini, M., Aldini, G., Bombardelli, E., MorazzonI, P. and Morelli, R. : Arzneim.-Forsch./Drug Res., 44, 592 (1994).

22）龟山畺由美: 生物之化学, 36，766 (1998).

23）川岸舜朗-森光康次郎 : 生化学実酫法 38 食品中 
の生体機能調節物研究法, 川岸舜朗編, p. 85, (1996).

24) Ho, C.T., Chen, Q., ShI, H., Zhang, K.Q. and Rosen, R.T.: Preventive Medicine, 21, 520 (1992).

25）小島保彦: Food Style 21，2，25 (1998).

26）近藤美由紀・丁 宗鉄・山田陽城・清原䙾章 - 大
塚恭男: 和漢薬，16，76 (1983).

27) Shahat, A.A., Hammouda, F., Ismail, S.I., Azzam, S.A., Bruyne, T.D., Lasure, A., Poel, B.V., Pieters, L. and Vlietinck, A. J. : Planta Med., 62, 10 (1996).

(平成 11 年 2 月 16 日受付, 平成 11 年 4 月 14 日受理) 